\title{
Klaten Traditional Lurik Weaving: Adaptation Strategies and Inheritance Systems in Society
}

\author{
Ismadi $^{1}$, Tjetjep Rohendi Rohidi ${ }^{2}$, and Triyanto ${ }^{3}$ \\ \{Ismadi@uny.ac.id ${ }^{1}$, triyantoma57@gmail.com² ${ }^{2}$, \\ Faculty of Language and Art, Yogyakarta State University, Indonesia ${ }^{1}$, \\ Postgraduate, Universitas Negeri Semarang, Indonesia ${ }^{2,3}$
}

\begin{abstract}
Klaten traditional lurik woven handicraft is one of the local cultural products that has remained sustainable through the ages. Its existence experienced ups and downs caused by economic, social and cultural changes. This study aims to reveal the adaptation strategies and Klaten traditional lurik weaving inheritance systems. The results showed that: 1) the adaptation strategy undertaken by the Klaten traditional weaving crafters was to carry out an ecological adaptation by developing striated woven motifs based on market surveys, the use of natural dyes, and the combination of materials with natural fibers; social adaptation by applyingattitude narimo; and cultural adaptation by increasing the role of artisans in every cultural activity; 2) lurik weaving inheritance system includes education in the family and the local environment (informal), non-formal education through nyantrik, formal education (school). The implication of the adaptation strategy and the inheritance system makes the Klaten lurik weaving craft remain sustainable. In conclusion, Klaten's traditional lurik weaving is a symbol of the expression of ecological, social and cultural craftsman adaptation, as well as a system of inheritance in crafters' communities.
\end{abstract}

Keywords: striated weaving, adaptation strategies, inheritance.

\section{Introduction}

Traditional weaving is a cultural heritage that is still in great demand by most Indonesian people. Weaving is passed down from generation to generation traditionally. This can be proven by the relief of stone piles depicting a woman weaving [1]. As a cultural product that always interacts with the surrounding environment, weaving crafts are greatly influenced by environmental changes. The changes meant are social, economic, legal, political, security and norms/values of local customs. The beginning of the creation of weaving, other than as a clothing material, the motifs and colors have their own values related to prana social status, religious and religious activities, traditional ceremonies, and cultural activities. Over time, customary and cultural activities that become traditions and cultural routines that are sacred are also beginning to be marginalized, as a result the weaving function inherent in various traditional activities is slowly beginning to be biased. This is not strange, because life is essentially always evolving (changing), and any changes that occur in society will always pose a risk of social life or social uncertainty [2]. As a result of these changes, most of the traditional weaving crafts in several regions in Indonesia have died. 
However, there are things that are different from traditional Klaten striving handicrafts, which have their own vitality. In its journey, Klaten lurik weaving has experienced a period of glory, a period of receding, a period of survival, a period of near-death, and is now revived. Mangifera explains that lurik weaving is the most popular industry in Klaten Regency and is one of the characteristics of Klaten Regency [3]. It was further explained that the preservation of the Klaten lurik woven cloth is supported by the Klaten District Government Policy number 025 / 575/08 dated June 25, 2008 concerning the trial use of the Klaten traditional woven or batik clothing. On the other hand Wardani in his research explained that the Klaten striated fabric in its preservation efforts places more emphasis on the use of natural dyes and the process of making striated woven fabric using Non-Machine Weaving Equipment (ATBM) [4].

The existence of the Klaten lurik weaving craft cannot be separated from the adaptation efforts of the lurik weavers in responding to changes. The expression of the adaptation of weaving crafts in this case of the weaving craftsmen is certainly different, according to the knowledge system, attitudes, beliefs, customs, and environmental norms of each. No doubt the development of clothing and fashion continues to run. Woven clothing with certain motifs that were originally used in traditional ceremonial clothes, currently the woven cloth has been used in various events. Likewise with the motifs and patterns used, formerly certain motives and have meaning but now more diverse and no longer pay attention to the meaning of the motifs displayed [5]. The inheritance system carried out by the craftsmen also contributed in maintaining the continuity of the Klaten lurik woven cloth to this day. Based on this background, this paper aims to examine and uncover: adaptation strategies and education systems that inherit Klaten's traditional lurik weaving in an effort to maintain its existence in the face of socio-cultural change.

\section{Methods}

The method used in this research is qualitative research with an interdisciplinary approach that focuses on the study of anthropology in fine arts. Interdisciplinary approach: anthropology to explore the adaptation behavior of Klaten traditional weavers and striated weaving systems. Research Sites: lurik weaving craft centers in the Districts: Pedan, Trucuk, Cawas, Bayat, Juwiring, Karangdawa and Delanggu. Data and Data Sources: primary data (natural, human and cultural resources), knowledge systems, values, beliefs, adaptation capital, adaptation strategies, creative processes, and inheritance systems; secondary data (population, area, citizen activity document). Data Collection Techniques: observation, interviews, document data collection, data collection on individual experiences. Checking the viability of the data using triangulation techniques (source, time, technique). Qualitative data analysis is done interactively through the process of collecting data, reducing data, presenting data, and drawing conclusions [6]. 


\section{Results and Discussion}

\subsection{Klaten Traditional Lurik Weaving}

The birth of Klaten lurik weaving began around 1938, with the initiation of the "Sumber Sandang" home weaving business by Suhardi Hadi Sumarto in a Jalinan Hamlet, Kedungan Village, Pedan District (http://jogja.tribunnews.com/2016/12/30/). At that time the business had provided a livelihood by providing employment for the surrounding residents and several sub-districts, such as: Pedan, Trucuk, Cawas, Bayat, Juwiring, Karangdawa and Delanggu. Furthermore, armed with weaving expertise, the employees started their own traditional lurik handicraft business in their respective regions.

Data from the Department of Industry, Trade, Cooperatives, and Small and Medium Enterprises (Disperindagkop and UKM) of Klaten Regency, in 2006 there were 300 ATBM businesses with a workforce absorption of 1,090 people, whereas in 2008 , that number had jumped to 1,036 units with absorption workforce of 3,108 people. (https://nasional.kompas.com/read/2010/12/24/05280236/). In 2016 there was an increase in the number of traditional lurik weaving craftsmen, namely as many as 1,078 business units / crafters but there was a decrease in the absorption of the number of workers, which was only 2,186 people [3].

The activity of traditional lurik weaving handicraft has been running for almost three generations. This is reinforced by the speech of the leader of the lurik weaving lord, "Maju Makmur", namely Mrs. Suliyem (interview on 27 October 2018) [17] who said that weaving skills and the existence of weaving crafts in her village, namely Tlingsing Village, Cawas District started from her work as weaving laborers in weaving craft centers in the area of Pedan and Juwiring, which subsequently developed (done at home).

\subsection{Adaptation Capital}

The adaptation capital of the Klaten traditional lurik weaving crafters consists of nonmaterial and material capital. Non-material capital is the expertise of weaving itself. Weaving expertise of the artisans was originally obtained during the workforce at the lurik weaving company "Sumber Sandang" Pedan. Weaving workers from various regions then passed on their expertise to children, relatives, and teachers with neighbors (nyantrik) (Suliyem, interview on 27 October 2018) [17]. Some of these skills as the first non-material basic capital owned by the craftsmen to adapt in running their businesses.

The next basic capital is the attitude of narimo ing nadyan pandum may sethithik (accept what God has given even a little). For some lurik weaving artisans, they also run businesses in addition to getting results, also want to get comfort and peace in life (Suliyem, interview on 27 October 2018) [17]. This attitude is the second adaptation capital for lurik weaving craftsmen to be able to survive amid the onslaught of the current of change. The Javanese philosophy of the Waton people, which means "even if it works slowly as long as it is expected" is an implication of the idea that they are working and if it works slowly or quickly, the results will be shared by other community members [7]. Two basic capitals as explained previously are non-material capital that equips Klaten traditional lurik crafters to adapt to environmental changes.

\subsection{Adaptation Strategy}

Klaten traditional weaving craft is a form of community activity to maintain existence in overcoming economic problems. In addition, this traditional striated woven craft is also a form 
of behavioral expression, and is often seen as one of the strong characteristics of local cultural identity, meaning that the weaving works are reflected in value systems, traditions, environmental resources, life necessities, and patterns of human behavior. Striated weaving is part of a culture that has a dynamic nature, not something that is static or rigid, so the ability to change for strived weavers is an important trait. Without it, culture is unable to adapt to changing circumstances [8]. The ability to change can also be said to be an adaptation strategy for Klaten lurik weaving craftsmen.

A culture for the owners or supporters of the community has a very valuable value in carrying out their lives either as individuals or as citizens [9]. This is the basic foundation of the craft of Klaten weaving to adopt an adaptation strategy by considering the values of attitudes, beliefs, customs, and environmental norms of each. First, the weaving craftsmen take steps to preserve traditional and classical motifs (such as reject watu, sticky rice, salak sticky rice, oblique gravestone, sodo sak ler, bayem flower, flower blossom, calf blades, rinding putung, sliced udan, broken tumbar, and the like) which continues to be produced to meet the needs of cultural activities and user community trust. For example, the striated woven fabric which is rejected is used for seven monthly pregnant women or in Javanese society commonly called mitoni. This motif striated woven cloth is also commonly used for ceremonial salvation or ngruwat. In addition, the artisans also innovate products by designing new motifs based on market surveys. Some examples motif design results artisans weaving striated creations are: Sapit urang kawung ornate, kluwung ornate peacock, ornate contemporary striated kawung and cleavers, machetes and ornate contemporary flora (Widodo, interview dated October 30, 2018). Designs are made through creations of shapes, configurations, or compositions of lines or colors, or lines and colors, or combinations that give an aesthetic impression and can be used to suit market demands [10]

Second, the weaving crafters always attend exhibitions, seminars, fashion shows and product competitions in various regions. This strategy is carried out to introduce Klur Lurik fabric products to the wider community. Some national events that are often followed by lurik weaving craftsmen are: INACRAFT, Indonesian Creative Work (KKI) organized by Bank Indonesia, Gebyar IPPKINDO, MAKERFEST, Indocraft, WARISAN (Wasiat Agung Negeri Nusantara), and annual activities held in Klaten. The annual activity that serves as an exhibition for Klaten traditional lurik weaving businesses is the "Klaten Lurik Carnival" organized by the Klaten Regency Government (Suliyem, interview on 27 October 2018) [17].

Third, natural coloring becomes a technical strategy in dealing with the issue of go green, including the issue of the environment with the condition of green land getting narrower, pollution and pollution on earth is increasingly worrying. In addressing this, some craftsmen made a breakthrough to return to the natural colors taken from plants around, such as kesumba seeds to produce red or yellow, mango tree bark to produce a yellow or green color, root pace and jackfruit tree bark to produce yellow, tarum (leavestom)to produce blue, and mahogany bark to produce light brown, dark brown, and red colors [11].

The three expressions of adaptation are in accordance with Brown's adaptation concept which can be used in the study of the forms of life of organisms and social life. Brown distinguishes the existence of three aspects in the whole system to explain the form of social life as an adaptation, namely ecological adaptation, social adaptation and cultural adaptation [12]. Ecological adaptation is an effort of social life to adapt to its physical environment, in this case it can be seen in the business of adjusting Klaten lurik weavers who design new motifs based on market surveys, start using natural colors, and combine lawè yarns with various materials from nature. Social adaptation related to social institutions created by a social life to control or reduce conflict, this can be seen in the application of capital adaptation 
in the form of narimo ing nadyan pandum may sethithik (accept what God has given even a little) and gaweane awake dewe (proud of own work). Cultural adaptation related to social processes, an individual will try to get used to a place in social life to be able to participate in its activities, it can be seen an increase in the participation of lurik weavers in various cultural activities (exhibitions, carnivals, competitions, and worshop) in regional and national scope.

\subsection{Inheritance System}

Cultural inheritance is a way for a group of people in a society or culture to convey a number of knowledge or holdings in passing on culture to another generation or group of people in order to preserve culture. Koentjaraningrat explains that the process of cultural inheritance is done through the process of enculturation (civilization), and the process of socialization (learning or studying culture) [13]. The Klaten traditional lurik weaving inheritance system is carried out in several ways. First, the inheritance system that takes place through education in the family. Most of the craftsmen apply parenting to their children by providing weaving skills after the child comes home from school. This confirms that education is the process of inheriting the cultural values of a society to the next generation, so that education cannot be separated from the culture of its people [14].

Second, the system of inheritance is nyantrik namely by studying with neighbors by asking for an explanation while also helping in weaving activities without expecting a salary from the work. Thisactivity eccentric is usually done for someone who wants to be able to weave but from parents or family tree nobody can or pursue this weaving activity (Widodo, interview on 27 October 2018) [15].

Third, the inheritance system through formal education. Conceptually, education is an effort to preserve and develop culture as an adaptive and creative guide or strategy in utilizing local environmental resources [16]. Some craftsmen send their children to school by enrolling in the Department of Textile in the hope that their children will get a textile education, especially weaving competency. This has only been done since the establishment of the Rota Bayat 1 Vocational High School in Klaten around 2010.

Based on this explanation, it can be stressed that the inheritance system in the lurik crafters community includes education in the family or by seeing firsthand the weaving activities in the local area (informal), non-formal education through nyantrik, formal education (school). The implication of the implementation of the adaptation strategy and inheritance system that is implemented makes the Klaten striated woven handicraft sustainable in the midst of environmental changes.

\section{Conclusion}

Based on the results and discussion, it can be summarized as follows: The adaptation strategy carried out by the traditional Klaten weaving crafters is to carry out an ecological adaptation strategy in the form of adjusting new motif designs based on market surveys, use of natural colors, and combiningyarns lawè with various materials from nature ; social adaptation in the form of the application of capital adaptation in the form of narimo ing nadyan pandum may sethithik (accept what God has given even a little) and gaweane awake dewe (proud of his own work); and cultural adaptation in the form of increasing the participation of lurik weavers in various cultural activities (exhibitions, carnivals, competitions and worshop) in regional and national scope. The inheritance system in lurik weaving crafters communities includes 
education in the family (informal),education non-formal through nyantrik, formal education (school). The implications of the adaptation strategy and the inheritance system applied have made the Klaten lurik weaving craft remain sustainable until now. 


\section{References}

[1] Suwati, K. (2007). Variety of Traditional Indonesian Ornaments of Ikat Weaving. Gramedia Main Library of Indonesia.

[2] Rai Utama, I Gusti. (2013). Philosophy of Science and Logic. Bandung: Dhiyana Pura University.

[3] Mangifera, Liana. (2016). Strategies for the Development of Striated Industry as a Regional Superior Product in Klaten https://core.ac.uk/display/73938057 downloaded 29 January 2018.

[4] Wardani, Niken Dyah Ayu Kusumaning. (2011). Pedan Striated Fabric and Preservation Efforts. Essay. Semarang: Department of Sociology and Anthropology, Semarang State University.

[5] Guslinda and Kuniawan, Otang. (2016). Changes in form, function and meaning of Songket Siak Weaving in the Malay Community of Riau. Primary Journal. 1 (4).

[6] Ghony, M. Djunaidi and Almanshur, Fauzan. (2012). Qualitative Research Methods. Yogyakarta: Ar-ruzz Media.

[7] Siswanto, Dwi. (2010). The Influence of Javanese People's Life View on the Leadership Model (Social Philosophy Review). Journal of Philosophy. 20 (3), 198-216.

[8] Ditto, A. and Yuliarni. (2017). The Impact of the Development of Ceramic Crafts on the Social and Cultural Life of the Community in Kanale Andaleh. Journal entry Sociohumaniora. 3 (1), $10-19$.

[9] Triyanto. (2014). Culture-based Arts Education. Imagination Journal. 8 (1), 33-42.

[10] UU no. 31 of 2000 concerningIndustrial Design.

[11] Maharani, Brigita. (2011). Impact of the Circular Letter of the Regent of Klaten on the Use of Non-Machine Weaving Equipment (Atbm) Office on the Development of Non-Machine Weaving Equipment Industry (ATBM) in Klaten District. Essay. Yogyakarta: Sanata Dharma University Yogyakarta.

[12] Hendro, Eko Punto. (2000). When Weaving Changes Troso Village. Semarang: Kharnolis Flag Publisher,

[13] Koentjaraningrat. (1987). History of Anthropological Theory. Jakarta: UI-Press.

[14] Sukmayadi, Trisna. (2016). Study on Character Based Values of Local Wisdom in Indigenous Communities of Kuta Village, Tambaksari District, Ciamis Regency. Civics Journal. 10 (1), 97112.

[15] Widodo (52 years old). Strived Woven Craftsman Tlingsing Village, Tlingsing Village, Cawas District, Klaten Regency.

[16] Rohidi, TR (2014). 2014. Art Education Issues and Paradigms. Semarang: Cipta Prima Nusantara.

[17] Suliyem Persons (57 years old). Chairperson of "Maju Makmur" lurik weaving lurik, Tlingsing Village, Cawas District, Klaten Regency. 